\title{
超精密軸受用鋼球のラッピングシステムに関する研究*
}

\author{
後藤 賢 治** 水 本 洋***
}

A Lapping System for Ultra-precision Bearing Balls

Kenji Goto and Hiroshi Mizumoto

The lapping mechanism for obtaining ultra-precision bearing balls is analyzed by simulation and experiments, and effective lapping system for mass production of balls is proposed. In the simulation, the configuration of a ball is represented by a Fourier series. Then the ball is assumed to be lapped between two lapping plates having $\mathrm{V}$-shaped grooves with several $\mathrm{V}$-angles, and the configuration of the lapped ball is represented by another Fourier series. The correction in profile is evaluated by the decrease of Fourier factors. In the experiments, lapping plate with R-groove (round groove) and S-groove (round groove having a pit) are used instead of V-shaped grooves for increasing the contact area between balls and the grooves. The experiments show that the combination of $\mathrm{R}$ and $\mathrm{R}(\mathrm{R}+\mathrm{R})$ is effective to reduce the waviness of even order harmonics, and $\mathrm{R}+\mathrm{S}$ decreases the 3rd-harmonic in waviness. The combination of $\mathrm{S}+\mathrm{S}$ decreases the $3 \mathrm{rd}$, however increases the $2 \mathrm{nd}$ and the 4 th-order. To decrease every order harmonics, a lapping system with 3 steps $(R+R \rightarrow R+S \rightarrow R+R)$ is proposed. The steel balls finished by this system show the following figures; roundness $=18 \mathrm{~nm}$ and $R_{\mathrm{a}}=2 \mathrm{~nm}$.

Key words: lapping, ball bearing, ball screw, steel ball, Fourier series, roundness, profile, waviness, sphericity

1.はじめに

近年, 機器の小型化, 高性能化に伴い, HDD のスピンドル モータやVTRのドラムスピンドル用の小径玉軸受には低振動 で高い回転精度が要求されている. これらの機械要素に転動体 として使用されている球の精度が軸受の性能に極めて大きな影 響を及ぼすために，最近では真球度が $50 \mathrm{~nm}$ 以下の超精密球 が必要とされ, 球の高精度化への要求は今後ますます高李るも のと考えられる.このよらな高精度の球はラッピングを最終工 程として量産される. 球のラッピングメカニズムは複雑であ ク，その技術の多くをまだ経験に頼っている部分も多いが，こ れまでにいくつかの真球度矯正メカニズムについての研究 ${ }^{1) ~ 31}$ がなされている.これらの研究では球の形状矯正は選択原理に 基づいて特定の次数の山が他の次数の山よりも多く研磨される ことによるとしている.このような研磨メカニズムによると， どの次数成分も研磨とともに減少し, 実際の研磨過程で見られ る特定の次数成分が増加して形状が変化する現象は説明できな い.

そこで本研究ではシミュレーションによって球とラップとの 接触点を仮想的に除去して新たな形状を作り出し，それを Fourier 級数で表すことにより球の形状誤差が研磨の進行とと あにどのように推移するかを解析することで従来の研究では説 明できなかった研磨メカニズムについて検討する. そしてシ ミュレーションの結果をもとに種々の溝形状を組み合わせた ラッピングシステムを編成して鋼球の加工実験を行い, 従来の 加工法では困難であった真球度 $50 \mathrm{~nm}$ 以下の超精密軸受用鋼 球が量産加工できることを明らかにする。

2. シミュレーションによる形状矯正の解析

2.1 シミュレーションの方法

量産に使用されるコンベア付き球研磨機では, 球はコンベア

* 原稿受付 平成 7 年 8 月 24 日

** 正 会 員 (株)天过鋼球製作所 (門真市上野口町 1-1)

*** 正 会 員 鳥取大学工学部（鳥取市湖山町南 4-101）
からラップの中に供給され, 同心円状の溝の中を自転しながら 公転する間に研磨される. 球はラップの溝を 1 周した後にコン ベア内に排出され，コンベアの回転によって輸送されて再び ラップに供給される．このサイクルを繰り返すことによって球 が少しずつ研磨される. ラップ中の球を観察したところ，その 自転軸の傾きはラップ溝を 1 周する間，泀とんど変化しないこ とがわかった，そしてコンベアに排出されるたびに球の向きが ランダムに変わり, 次回ラップに入ったときに自転軸が変化す る. そこで，このような状況を次のような 2 次元にモデル化し て考えることとした．まず，ラップ溝の中での球は転がること なくラップとの接触位置は変わらず，滑ることによってその接 触点が加工されるものと仮定する. そして球が次回再びラップ に入ったときに接触点が変化して前回と別の接触点が研磨され ることとした. このように考えることで球形状の矯正過程のシ ミュレーションを行った.

図 1 は溝断面がそれぞれ開さ角 $\alpha$ と $\beta$ の V 溝を持ったラッ プの間に幾何学的な形状誤差をもった球をはさんだ状態を表し ている. 球は $X$ 軸を自転軸としてラップと接触するのである が，ここでは上述のよらに球の回転は考慮しない。尤 $X^{\prime}$ 軸

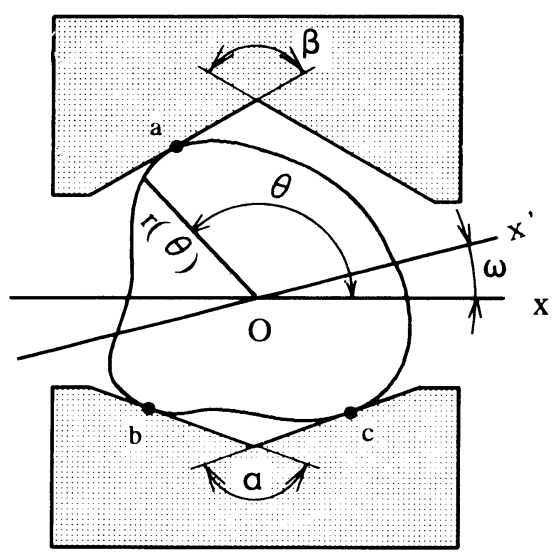

Fig. 1 A ball having geometrical error and a pair of lapping plates holding the ball 


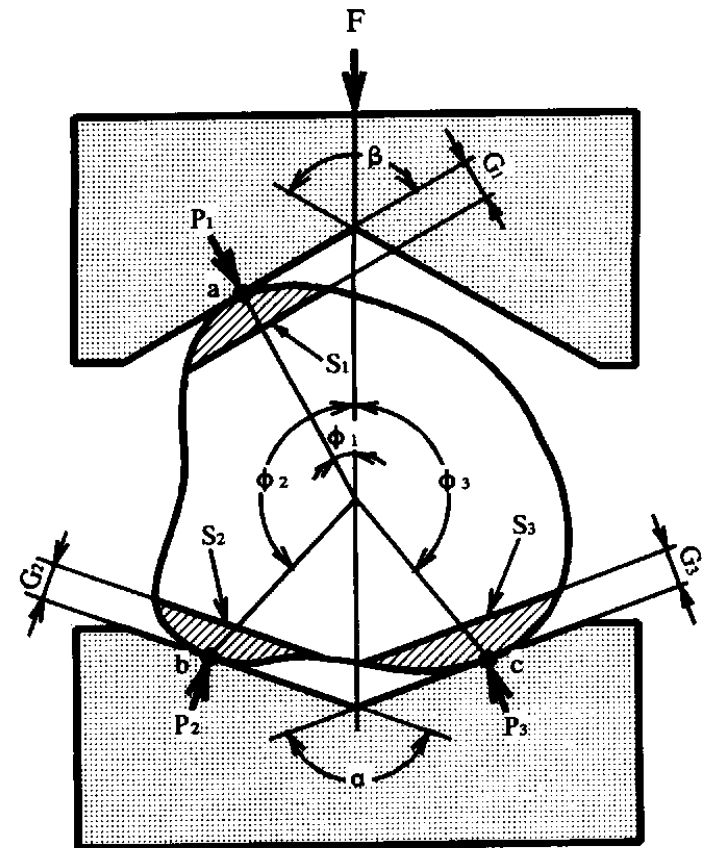

Fig. 2 Contact points and profile of ball lapped out

は球に固定された座標軸で, 回転軸との間の角度 $\omega$ を球の傾 き角とする. 図中の $\mathrm{O}$ を原点とする極座標をとって, 球の断 面形状を式 (1)のように Fourier 級数により表現する.

$$
r(\theta)=a_{0}+\sum_{k=1}^{\infty} a_{k} \cdot \cos \{k(\theta-\omega)\}+\sum_{k=1}^{\infty} b_{k} \cdot \sin \{k(\theta-\omega)\}
$$

ここで, $a_{0}$ は球の平均直径, $a_{k}, b_{k}$ はFourier 係数, $k$ はFourier 級数の次数で, $a_{k}, b_{k}$ が $k$ 次の形状䜋差（ウェビネス）の 大きさを表している。

以下には球研磨工程のシミュレーションの具体的手順を示 す.なお, 球の初期形状は 2 次成分, 3 次成分, および 4 次成 分のみの形状誤差をるつ 3 種類とし，ラップはV 溝と平面お よびV清とうし（開き角は等しい）の組合せとした。

（1）球の形状誤差とラップ溝の開き角を与える.

（2）球の傾き角 $\omega$ を一様乱数で与える.

（3）傾き角 $\omega$ でラッブ溝と接触している研磨前の球の幾何 学的形状を式 (1) を使って Fourier 級数で表す.

（4）このときのラップ溝と球の接触点 a, b,c（接触角 $\phi_{1}$, $\phi_{2}, \phi_{3}$ )を求める（図 2 は球とラップとの接触状態を示し たものである).

（5）次に接触点 a, b,c に働く力を求める.

球とラッブを剛体と仮定するとラッブは半径方向に拘束 されているので球に形状鿁差があれば上側ラップの左右の 面から球までの距離に差が生じる. その結果, 球とラップ は上側ラップのいずれかの面と下側ラップの両面との 3 点 接触となる. ラッブ全体には荷重 $F$ が作用しており, 球 は接触点 $\mathrm{a}, \mathrm{b}, \mathrm{c}$ でそれぞれ分力 $P_{1}, P_{2}, P_{3}$ を受けているる のとすると, 力の釣合いより

$$
\begin{aligned}
& -P_{1}+P_{2} \cos \left(\pi-\frac{\alpha}{2}-\frac{\beta}{2}\right)+P_{3} \cos \left(\frac{\alpha}{2}-\frac{\beta}{2}\right)=0 \\
& -F \cos \frac{\beta}{2}+P_{2} \sin \left(\pi-\frac{\alpha}{2}-\frac{\beta}{2}\right)+P_{3} \sin \left(\frac{\alpha}{2}-\frac{\beta}{2}\right)=0
\end{aligned}
$$

が成立し，式 (2) と式 (3) から次式を得る.

$$
P_{2}=\xi \cdot P_{1}, P_{3}=\eta \cdot P_{1}
$$

$$
\begin{aligned}
& \xi=\frac{\sin \left(\frac{\alpha}{2}-\frac{\beta}{2}\right)-\left\{\frac{\cos (\beta / 2)}{\sin (\beta / 2)}\right\} \cos \left(\frac{\alpha}{2}-\frac{\beta}{2}\right)}{\cos \left(\pi-\frac{\alpha}{2}-\frac{\beta}{2}\right) \sin \left(\frac{\alpha}{2}-\frac{\beta}{2}\right)-\sin \left(\pi-\frac{\alpha}{2}-\frac{\beta}{2}\right) \cos \left(\frac{\alpha}{2}-\frac{\beta}{2}\right)} \\
& \eta=\frac{\sin \left(\pi-\frac{\alpha}{2}-\frac{\beta}{2}\right)-\left\{\frac{\cos (\beta / 2)}{\sin (\beta / 2)}\right\} \cos \left(\pi-\frac{\alpha}{2}-\frac{\beta}{2}\right)}{\sin \left(\pi-\frac{\alpha}{2}-\frac{\beta}{2}\right) \cos \left(\frac{\alpha}{2}-\frac{\beta}{2}\right)-\cos \left(\pi-\frac{\alpha}{2}-\frac{\beta}{2}\right) \sin \left(\frac{\alpha}{2}-\frac{\beta}{2}\right)}
\end{aligned}
$$

（6）接触点 $\mathrm{a}, \mathrm{b}, \mathrm{c}$ の研磨量を求める.

球をラップ間で $\theta$ 方向に回転させたときの球上端の上 下動は次式で与えられる。

$$
\begin{aligned}
H(\theta)= & \mu(\alpha, k)\left[\sum_{k=2}^{\infty} a_{k} \cdot \cos \{k(\theta-\omega)\}\right. \\
& \left.+\sum_{k=2}^{\infty} b_{k} \cdot \sin \{k(\theta-\omega)\}\right]
\end{aligned}
$$

ここで $\mu(\alpha, k)$ は払大係数と呼ばれ，次式で与えられる。

$$
\mu(\alpha, k)=1+\frac{\cos \left\{k\left(\frac{\pi}{2}+\frac{\alpha}{2}\right)\right\}}{\sin \frac{\alpha}{2}}
$$

色々な智の球がラップにはさまれているすのとして $H(\theta)$ が最小になる方向を向いた球の振幅 $H(\theta)_{\min }$ を基 準にすると，干渉量 $\Delta H(\theta)$ は次式で与えられる.

$$
\Delta H(\theta)=H(\theta)-H(\theta)_{\min }
$$

そこで, 研唐量は干渉量に比例するるのと仮定すると任意

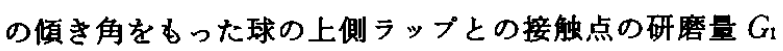
は次式で表される。

$$
G_{1}=\lambda \cdot \Delta H\left(\phi_{1}\right)+\varepsilon
$$

ここで, $\lambda$ および $\varepsilon$ は定数である.

他の接触点の研磨量はそれぞれ接触点にかかる力に比例 するるのと考光ると式 (4)より, 接触点 b, c の研磨量 $G_{2}$, $G_{3}$ を次式により求めることができる（四 2 参照).

$$
G_{2}=\xi \cdot G_{1}, G_{3}=\eta \cdot G_{1}
$$

（7）研磨されて新たにできた面の式を求める.

球は図 2 に示すように接触点で加工を受け，ラップの溝 に平行にフラットに研磨されるものとすると, ハッチンク の部分が研磨除去され，ラップに平行な面 (直線) $\mathrm{S}_{1}, \mathrm{~S}_{2}$, $\mathrm{S}_{3}$ が現れる.

（8）手順 (2)にもどり研磨面 $\mathrm{S}_{1}, \mathrm{~S}_{2}, \mathrm{~S}_{3}$ と研磨されなかった 面の形状から, 研唐後の球の新しい形状を改めて Fourier 級数で表す.

（9）このよらなプロセスを 1 球につき 10 回ずつ絽り返し， 10 球について各次数のウエビネス振幅の変化を計算する ことでラッブの組合せの影箒を評価する.

\section{2 シミュレーションの結果}

$\mathrm{V}$ 溝付きと平面の場合の計算結果を図 3 (a) （d) に示す. 図3（a）は10個の球のウェビネスの3次成分の研磨回数に伴 ら振幅变化を表したるのである，毎回，乱数により与えられる 頓き角 $\omega$ の推移が異なれば，個々のウェビネスの変化の状態 にも差が生じているが，研磨回数が増加するにつれてどの球す 定性的には類似の傾向を示していることがわかる. したがっ て, 図 3 (b) 〜 (d) ではラッブの溝形状とウェビネス变化の関 係を 10 個の球の平均值の変化で評価することとする. 図 3 よ り 2 次成分および 4 次成分はV满開き角 $\alpha$ が大きいほど振幅 短正速度が大きいか， 3 次成分の魄正には小さな角度の $\alpha$ が䔔 


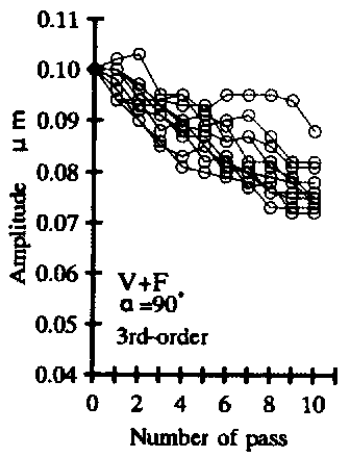

(a) The change in amplitude of 3rd-order in waviness of ten balls

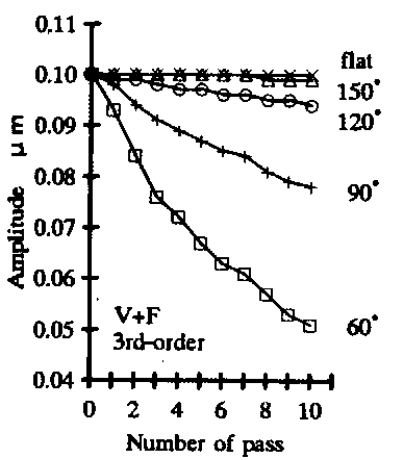

(c) The average of amplitude of balls (3rd-order)

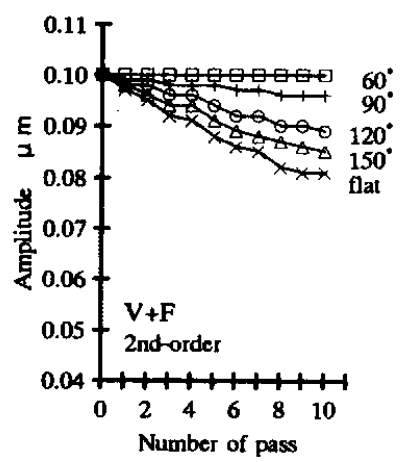

(b) The average of amplitude of balls (2nd-order)

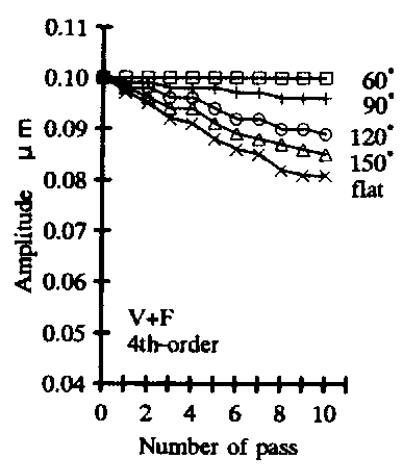

(d) The average of amplitude of balls (4th-order)

Fig. 3 Simulated change in waviness ( $V$-groove+Flat)

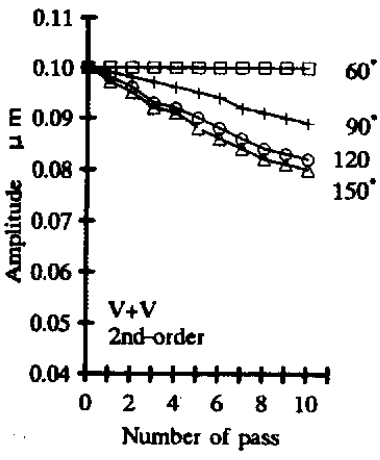

(a) The average of amplitude of balls (2nd-order)

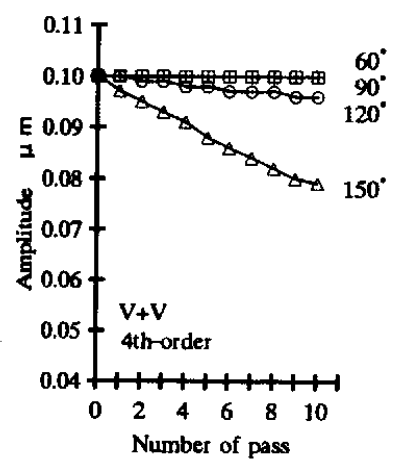

(c) The average of amplitude of balls (4th-order)

Fig. 4 Simulated change in waviness (V-groove $+V$-groove)

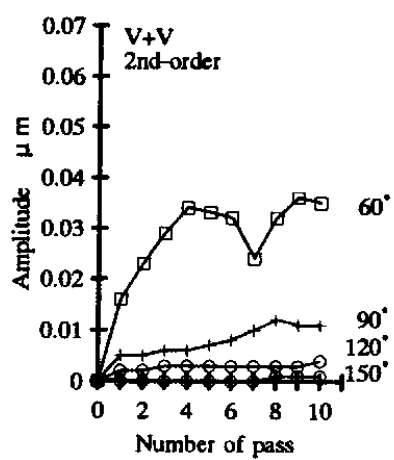

(a) 2nd-order

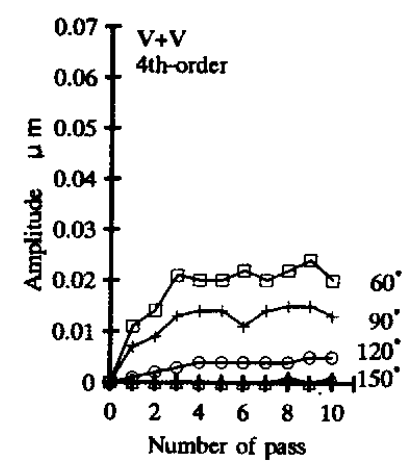

(b) 4th-order
Fig. 5 Increase of 2nd-order and 4th-order waviness in a ball having large 3rd-order waviness

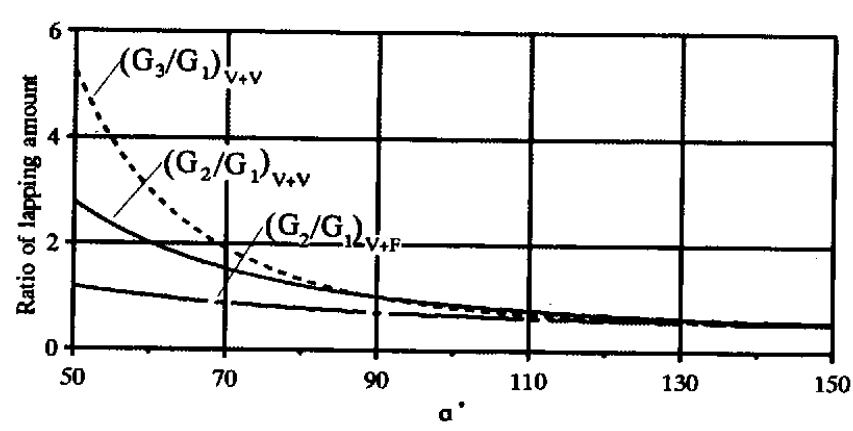

Fig. 6 Comparison of lapping amounts in $\mathrm{V}+\mathrm{F}$ and $\mathrm{V}+\mathrm{V}$

していることがわかる.

次にV涂ど5しの組合せの場合の結果を图 4 (a)〜 (c) に示 寸. 図 4 より 2 次成分および 4 次成分の振幅を下げるには図 3 の場合と同様に大きな角度の $a$ が效果的であり，一方，3次成 分を低減するには小さな角度の $\alpha$ が適していることがわかる. しかも，V 溝どうしの場合は， $\alpha か ゙ 90^{\circ}$ 以上では，V 㩐と平面 の組合せに比べて稪正能力が大きい，ただし，図4(b) からわ かるように, 3 次成分のみの球を研磨した場合， $\alpha か ゙ 90^{\circ}$ より 小さくなると矯正速度が $90^{\circ}$ のときよりむ低下する現象が見ら れる.このことを次に考察する。

図 5 は初期形状の誤差が 3 次成分のみの素球をV溝どうし で研磨した場合の，2次および 4 次成分の変化の状況を表した

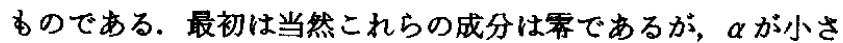
い場合には研磨回数が増えるにつれて 2 次，4次成分が増加し ている. 初期形状㕵差が 2 次，あるいは 4 次成分のみからでき ている球の場合でる研磨を進めていく過程で同様に最初は存在 しなかった他の次数の山が発生するが，これらの次数成分の増 加量は小さい，このよらな初期形状による差は接触点の研磨量 の此の違いに起因するすのと考えられる.

图 6 は，3 次成分のみの素球についてV清と平面执よび両 面 V 溝どうしで研磨した場合について, 図 2 の接触点 a の研 磨量 $G_{1}$ に対する接触点 $\mathrm{b}, \mathrm{c}$ の研磨量 $G_{2}$ およよび $G_{3}$ の比を表し

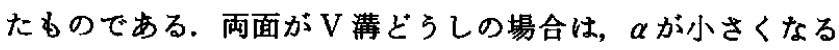
につれて接触点 $\mathrm{a}, \mathrm{b}, \mathrm{c}$ の研磨量 $G_{1}, G_{2}, G_{3}$ の差が急激に增加す る.この現象は 3 次成分のみの素球に起こり，2次および 4 次 成分のみの素球には起こらない，その原因は拡大係数 $\mu$ にあ る. 式（6）を部算すると， $\alpha$ が小さくなるにつれて，2次およ び 4 次成分の拡大俰数が減少するのに対して，3 次成分の払大 係数は增加していることがわかる. 扗大係数が小さければ千渉 量 (研磨量) が小さいので各接触点の間に研磨量の差が生じて 


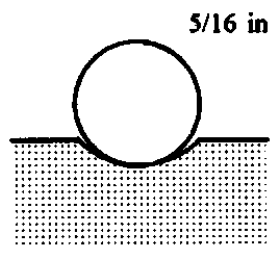

(a) R-groove instead of flat

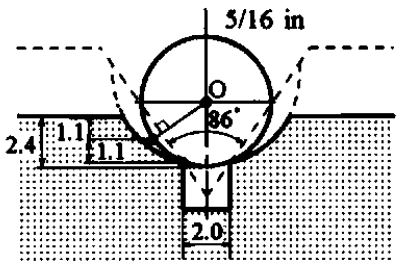

(b) S-groove instead of $\mathrm{V}$-groove
Fig. 7 Shape of grooves on lapping plates

る形状の変化には影謷しない。このよ5に 3 次成分のみをむつ 球を小さい開き角 $\alpha$ のV溝どうしで研磨すると，各接触点の 研磨量の差が著しく增加するためにもとはなかった 2 次および 4 次成分が徐々に増加し, 偶数多角形状に変化するものと考光 られ，結果として矯正速度が低下，あるいはときとして真球度 が悪化することになる.このようなシミュレーション結果は実 際のラッビングに拈いても経験される現象である.

以上のシミュレーション結果ををとめると下記のようにな る.

（1）球面上のラップとの接触点（接触軌跡）分布はランダ ムであり, 個々の球のウェビネスの变化の状態には差が生 じるが，研磨回数が増加するするにつれてどの球も定性的 には類似の傾向を示すようになる.

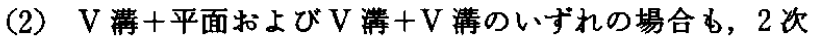
および 4 次成分はV 溝の開き角 $\alpha$ が大さいとよく稫正 される. 逆に 3 次成分の稪正には小さい $\alpha$ が効果的であ る.

（3）しかし，小さい $\alpha$ のV溝どうしの場合， 3 次成分の大 きい球を研磨すると, 研磨回数が増加するにつれて，3 次 成分が減少する代わりに 2 次および 4 次成分が増加する.

\section{3. ラッピンングの実検的解析}

\section{1 実検方法}

シミュレーションの結果, ウェビネスの 2 次, 3 次および 4 次成分を稪正するにはそれぞれの成分に有効な V 溝の開き角 があり，たたひとつの開き角のV 溝ですべての成分を镉正で きないことがわかった. したがって，すべての成分を短時間で 智正して真球度を向上させるには，いくつかの開き角の V 溝 を組み合わせる必要がある. また，純粋な V 溝や平面のラッ プで加工を始めると球との間の接触面積が小さく非常に研磨速 度が低い. 球と接触するラップの接触点は, 研唐工程の初期を 除けば摩耗して面接触になる、その結果, 初期形状が平面の場 合は加工を続けていくと球とほぼ同じ曲率をるった丸溝にな る. V 渆の場合る摩耗して球との接触面は球とほぼ同じ曲率の 丸溝になるが, この場合, 清底は球と接触しない.そこで, 初 期から高い研磨速度を得るために, 平面の代わりに図 7 (a)の ような球の曲率と等しい丸清 ( $\mathrm{R}$ 溝と呼ぶ)を, $\mathrm{V}$ 清の代わり に図 7 (b) に示すように溝底が球と接触しないように底にくぼ

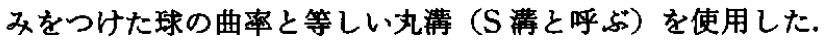
実験後の S 溝の底を観察すると全面均一な光沢をしており， 鋼球は溝の全面と接触しているるのと考劣られる.したがっ $\tau, \mathrm{S}$ 溝の深さ方向の中点と鋼球の中心を結ぶ直線が V 㩐の 法線に一致するすのとみなすと,この S 溝は開き角 $\alpha$ が約 $86^{\circ}$ の V 溝が摩耗した状隹とほ注等価と考えられる. 本研究の目

Table 1 Lapping process

\begin{tabular}{l|c|c|c}
\hline Lapping process & Step 1 & Step 2 & Step 3 \\
\hline Test No. 1 & $\mathrm{R}+\mathrm{R}$ & - & $\mathrm{R}+\mathrm{R}$ \\
Test No.2 & $\mathrm{R}+\mathrm{R}$ & $\mathrm{S}+\mathrm{S}$ & $\mathrm{R}+\mathrm{R}$ \\
Test No. 3 & $\mathrm{R}+\mathrm{R}$ & $\mathrm{R}+\mathrm{S}$ & $\mathrm{R}+\mathrm{R}$ \\
\hline
\end{tabular}

Symbols show combination of grooves

Step 1

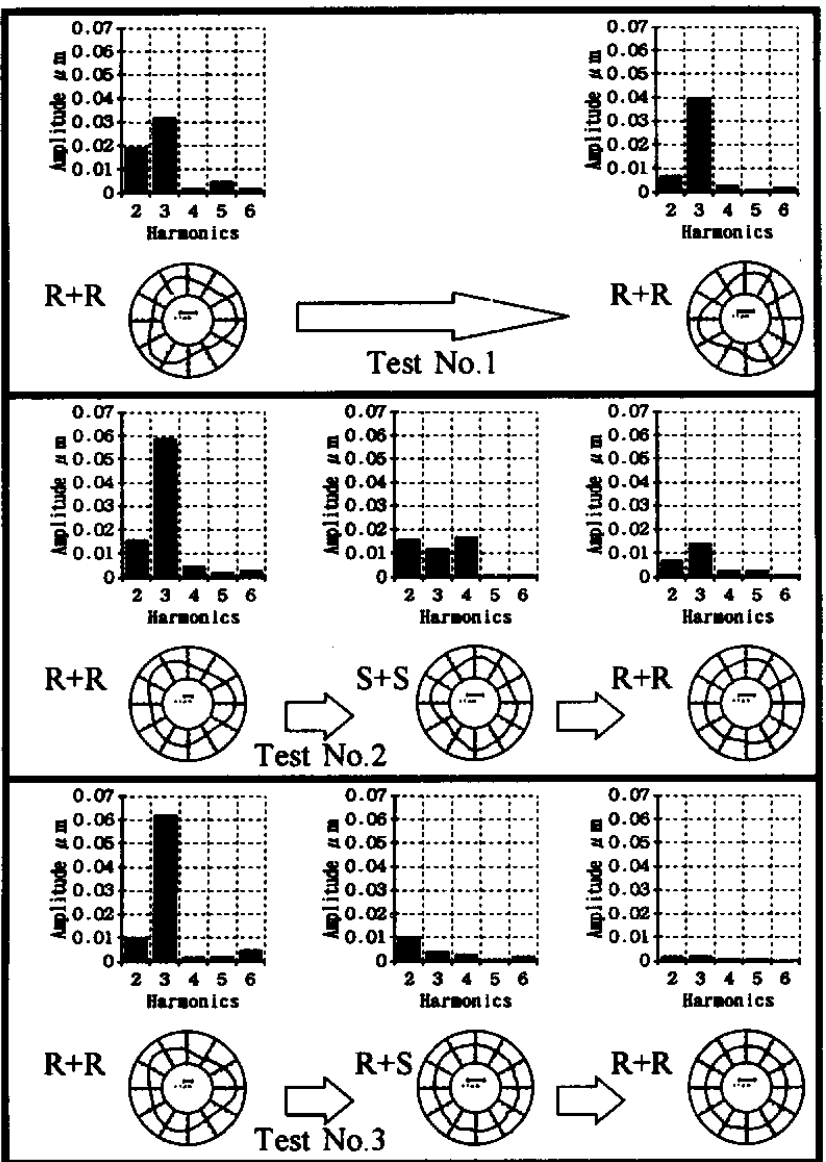

Fig. 8 Measured profiles of lapped balls

的は形状誤差の矯正に有効な溝を選択して高精度の球を効率的 に製作することにあるので，充 1 に示すような满の組合せから なる工程を編成して実験を行った。 ラッブの材質は䤻鉄で最外 径 $D_{\max }=\phi 640 \mathrm{~mm}$ で 8 本の溝を同心円状に持っている. 研磨 は3 工程とし, 研磨材は各工程ごとにStep 1: WA \# 4000, Step 2: GC\# 4 000, Step 3: ダイヤモンド 0 1.5 $\mu \mathrm{m}$ を用いた （ただし試験 No.1 ではStep 2 を省略した）。研磨機はコンべ 了付きの球研磨機を用い，熱処理と粗研削の完了した呼び $5 / 16$ (直径：約 $8 \mathrm{~mm}$ ) の高炭素クロム軸受鋼球を研磨した. 加工個数は 55000 個/ロットである.

\section{2 实験結果}

各研磨工程後の球の形状誤差の変化を図 8 に示す．また， ボール・ウェビネスメータで測定した低次（3〜15 次）のウェ ビネスの測定値の変化を图 9 に示す（これは1球につきランダ ムな 5 断面の平均値を求め, それを 5 球について測定し, さら にその平均値を示したものである).すずての試験の Step 1 で， $\mathrm{R}+\mathrm{R}$ (両ラップとるに $\mathrm{R}$ 溝) の組合せで加工した後は, 球形状は偶数次のウェビネスの振幅が減少し, 三角形になるこ とがわかる。このような三角形状はこの後, 試験 No. 1 に示す 


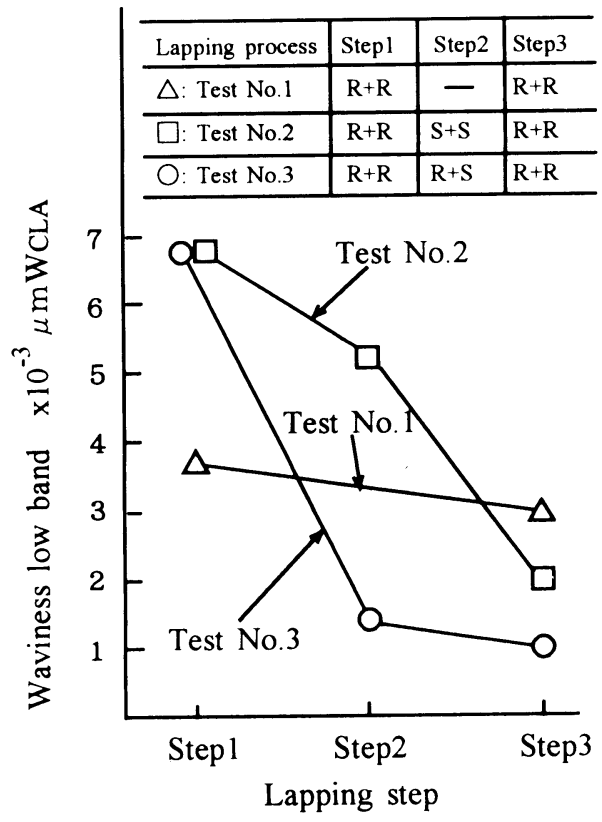

Fig. 9 Measured change in waviness

よらに細かい砥粒でさらに $\mathrm{R}+\mathrm{R}$ の組合せで続けて加工しても 矯正することがでさない。これは 2 点接触の場合, 偶数次成分 はよく矯正されるが，3次成分の矯正力は弱いためで, 平面ど らしの場合のシミュレーション結果と一致している.

試験 No. 2 の Step 2 で示されるよらに S+S の組合せで研磨 すると球形状は四角形になり, ウェビネス Low Band 值はあ まり減少しなかった。この結果は開き角 $\alpha$ が $90^{\circ}$ 以下の V 溝 どうしのシミュレーション結果とよく一致している. シミュ レーションでは, 3 次成分のみの球はV 溝どうしの研磨に よって, 3 次成分が矯正される代わりに, 最初は存在しなかっ た 2 次, 4 次成分が次第に増加することが示された. したがっ て S $+\mathrm{S}$ で研磨した場合には，3 次成分は矯正されて小さくな るが，2 次および 4 次成分は逆に増加したために三角形が四角 形に変化したと考えることができ，ウェビネス Low Band 值 があまり減少していないことになる. 引き続き, 試験 No. 2 の Step 3 で示されるよらに, この四角形の形状は次の R+R の 組合せで矯正された. これは, 偶数次成分は平面どうしの組合 せで矯正されることが示されたシミュレーション結果と一致し ている. しかしウェビネス Low Band 値は次の試験 No. 3 ほ どは減少しなかった. これは試験 No. 2 と試験 No. 3 の Step 2 完了時のウェビネス Low Band 值の差によるものと考えられ る.

試験 No. 3 に扣いて, Step 1 でできた三角形状をStep 2 の
$\mathrm{R}+\mathrm{S}$ の組合せで加工すると, 球の形状は 3 次成分がよく矯正 されて, 振幅の小さい多角形になった. そして, ウェビネス Low Band 值が非常に低い值にまで減少した.この結果は, 平面と開き角 $\alpha$ が $90^{\circ}$ 以下の $\mathrm{V}$ 溝との組合せのシミュレー ション結果と一致している. 先の $\mathrm{S}+\mathrm{S}$ 拈よびこの $\mathrm{R}+\mathrm{S}$ の実 験結果から, $\mathrm{S}$ 溝に対応する $\mathrm{V}$ 溝の開き角 $\alpha$ の推定値 $\left(86^{\circ}\right)$ は棌浽当な数値と考兄られる. $\mathrm{R}+\mathrm{S}$ の組合せの場合は 2 次 および 4 次成分を増加させることなく，3 次成分のみを矯正す ることができる， R+S の組合せで加工されたウェビネス Low Band 值の低い多角形の球は, 次の Step 3 で R+R の組合せで 研磨することにより, さらに真球度が向上しウェビネス值が減 少した.このような試験 No. 3 で製作した球の形状精度は真球 度が $18 \mathrm{~nm}$, 表面粗さ $R_{\mathrm{a}}=2 \mathrm{~nm}$ であった。 この精度は従来の システムでは困難であった, 現在最も要求精度の厳しい（真球 度 $50 \mathrm{~nm}$ 以下） HDD 用軸受に使用される球の仕様を満足して いる.

\section{4. ま と め}

球の研磨に打ける形状誤差の矯正過程をシミュレーションと 実験によって解析した結果, 次のことが明らかになった.

（1）両面ともに R 溝どうしの組合せは平面どうしの組合せ に対応して打り，偶数次成分はよく矯正されるが，3 次成 分の矯正力は弱い.

(2) $\mathrm{R}$ 溝と $\mathrm{S}$ 溝の組合せは平面と開き角 $\alpha$ が小さい $\mathrm{V}$ 溝 との組合せに対応して扣り，偶数次成分の矯正力は小さい が, 3 次成分はよく矯正される.

（3） $\mathrm{S}$ 溝どうしの組合せは開き角の小さい V 溝どうしの組 合せに対応して扣り，3次成分は矯正されるが，2次拈よ び 4 次成分が増加する. このよらな現象は従来の研磨メカ ニズムでは説明できなかった.

（4）異なった溝形状を組み合わせた 3 工程からなるラッピ ングシステム $(\mathrm{R}$ 溝 $+\mathrm{R}$ 溝で偶数次成分を, $\mathrm{R}$ 溝 $+\mathrm{S}$ 溝で 3 次成分を, 最後に $\mathrm{R}$ 溝 $+\mathrm{R}$ 溝で残った成分をさらに矯正 する）で加工すれば超精密軸受用鋼球が効率的に量産加工 できることを明らかにした. このシステムにより従来のシ ステムでは困難であった真球度 $18 \mathrm{~nm}$, 表面粗さ $R_{\mathrm{a}}=2$ $\mathrm{nm}$ の超精密軸受用鋼球が量産加工できた.

\section{参 考文 献}

1）津和秀夫：機械加工学, 養賢堂, (1979) 14.

2）市川茂樹, 小奈 弘, 吉本 勇: セラミックスボールのラッピング 加工，塑性加工春季講演会論文集，（1991） 353.

3）系魚川文広, 中村 隆, 舩橋鉀一：V溝ラップを用いた鋼球ラッピ ングの機構, 日本機械学会論文集 (C 編), 59, 562 (1993) 1906. 